\title{
OPTIMALISASI PEMANFATAAN LAHAN PEKARANGAN MENGGUNAKAN TEKNIK VERTIKULTUR UNTUK BUDIDAYA SAYURAN PENCEGAH STUNTING PADA BALITA GIZI BURUK
}

\section{Optimization Of Land Use Using Verticulture Technique For Vocational Stunting Prevention Vegetables In Nutrition Children}

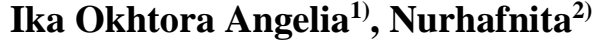 \\ ${ }^{1,2}$ Dosen Program Studi Teknologi Hasil Pertanian Politeknik Gorontalo \\ Email: ikaokhtora@poligon.ac.id ${ }^{1)}$
}

\begin{abstract}
ABSTRAK
Stunting merupakan ancaman utama terhadap kualitas manusia Indonesia, juga ancaman terhadap kemampuan daya saing bangsa. Hal ini dikarenakan anak stunted, bukan hanya terganggu pertumbuhan fisiknya (bertubuh pendek/kerdil) saja, melainkan juga terganggu perkembangan otaknya, yang mana tentu akan sangat mempengaruhi kemampuan dan prestasi di sekolah, produktivitas dan kreativitas di usia-usia produktif. Perbaikan pola makan dengan mulai merintis menanam tanaman tinggi zat besi dan asam folat di pekarangan rumah (Daun kelor, daun bayam hijau dan daun ubi) juga diperlukan khususnya untuk memenuhi kebutuhan ibu hamil dan MPASI balita. Pemanfaatan budidaya secara vertikultur mampu mempermudah ibu rumah tangga untuk menyediakan sayuran untuk keluarganya. Dengan semakin mudahnya akses terhadap sayuran pencegah stunting maka ancaman terhadap stunting terhadap balita dapat dikurangi angka prevalensinya.
\end{abstract}

Kata kunci : sayuran; pekarangan; stunting; makanan pendamping; balita

\section{ABSTRACT}

Stunting is a major challenge to the quality of Indonesian people, as well as a threat to the nation's competitiveness. This is because children are stunted, not only hinder their physical growth (short / dwarf), but also improve brain development, which of course will greatly affect the ability and achievement in school, increase and increase productivity in productive periods. Improving diet by starting to plant high substances and folic acid in the yard (Moringa leaves, green spinach leaves and sweet potatoes) are also needed specifically to meet the needs of pregnant women and MPASI toddlers. Farmers' homes to provide vegetables for households. Thus the more easy access to stunting prevention vegetables, the protection against stunting for infants can be calculated the prevalence rate.

Keyword : vegetables; yard; stunting; side dishes; toodler

\section{PENDAHULUAN}

Stunting merupakan masalah gizi kronis pada balita yang ditandai dengan tinggi badan anak yang lebih pendek dibandingkan dengan teman sebayanya. Selain itu, anak penderita stunting juga akan mudah terserang penyakit dan saat dewasa memiliki resiko mengindap penyakit degeneratif. Dampak anak yang menderita stunting selain terlihat dari fisik juga akan berpengaruh pada segi kecerdasan anak.
Angka kematian bayi dan balita di Indonesia yang disebabkan oleh kurang gizi masih sangat memprihatinkan. Jumlah prevalensi angka gizi buruk masih cukup tinggi yaitu mencapak 5,7\% dan gizi kurang 13,9\%. Sedangkan berdasarkan hasil riset kesehatan dasar (Riskesdas) Kementerian Kesehatan (2013) menunjukkan bahwa masalah stunting berada pada prevalensi $37,2 \%$. Jika merujuk pada hasil pemantauan gizi yang dilakukan 
Dinas Kesehatan provinsi Gorontalo (2014), prevalensi gizi kurang di Provinsi Gorontalo mencapai $14,44 \%$, dengan kontribusi terbesar ada pada Kabupaten Pohuwato yakni 10,9\% gizi kurang dan 2,2 \% gizi buruk (Profil Dinas Kesehatan Gorontalo, 2015)

Kasus gizi kurang dan gizi buruk di Provinsi Gorontalo banyak ditemukan di pedesaan khususnya di Kabupaten Pohuwato. Selain masalah kurangnya pemerataan dalam hal kesehatan dan rendahnya pemahaman mengenai gizi, kemiskinan juga menjadi salah satu faktor penyebab gizi kurang karena sulitnya akses untuk mendapatkan pangan yang bergizi. Masyarakat di Kabupaten Pohuwato mayoritas memiliki lahan pekarangan yang cukup luas, namun sejauh ini belum dimanfaatkan secara optimal oleh warga masyarakat. Perlu adanya sosialisasi penggalakan kegiatan penghijauan dan penanaman bibit khususnya tanaman sayuran sebagai alternatif upaya peningkatan asupan gizi yang optimal untuk mencegah stunting di wilayah tersebut.

\section{SOLUSI DAN TARGET LUARAN}

Sayuran merupakan salah satu contoh bahan makanan yang dibutuhkan oleh tubuh sebagai sumber vitamin dan mineral. Nutrisi yang terkandung dalam sayuran seperti vitamin, protein, dan zat-zat mineral lain dapat mendukung kesehatan tubuh manusia. Beberapa jenis sayuran yang cukup mudah ditemui di daerah tropis diantaranya adalah kangkung, bayam, kacang panjang, buncis, wortel, daun ubi, daun katuk, daun kelor dan kubis.

Indonesia merupakan negara tropis yang mendapatkan sinar matahari sepanjang tahun, sehingga memungkinkan tanaman sayuran untuk tumbuh dan panen sepanjang tahun. Hal tersebut menjadi alasan makin berkembangnya budidaya tanaman sayuran di tanah air. Selain itu sayuran juga memiliki nilai ekonomi yang tinggi, hal ini disebabkan karena nilai manfaatnya serta permintaan masyarakat akan konsumsi sayuran segar setiap harinya juga cukup tinggi.

Stunting merupakan ancaman utama terhadap kualitas manusia Indonesia, juga ancaman terhadap kemampuan daya saing bangsa. Hal ini dikarenakan anak stunted, bukan hanya terganggu pertumbuhan fisiknya (bertubuh pendek/kerdil) saja, melainkan juga terganggu perkembangan otaknya, yang mana tentu akan sangat mempengaruhi kemampuan dan prestasi di sekolah, produktivitas dan kreativitas di usia-usia produktif. Terdapat tiga hal yang harus diperhatikan dalam pencegahan stunting, yaitu perbaikan terhadap pola makan, pola asuh, serta perbaikan sanitasi dan akses air bersih (Moeloek, 2019). Perbaikan pola makan dengan mulai merintis menanam tanaman tinggi zat besi dan asam folat di pekarangan rumah (Daun kelor, daun bayam hijau dan daun ubi) juga diperlukan khsuusnya untuk memenuhi kebutuhan ibu hamil dan MPASI balita. Daun kelor misalnya, jika dikonsumsi oleh ibu menyusui dapat meningkatkan kinerja enzim oksitosin yang berimbas pada meningkatnya produksi ASI. Selain itu, daun bayam dan daun ubi dipilih sebagai sayuran pencegah stunting karena kandungan asam folatnya dan zat besinya yang tinggi dan mudah dibudidayakan sehingga bisa dijadikan sebagai sumber pangan alternatif lokal asli Indonesia yang bisa menurunkan angka stunting di Indonesia.

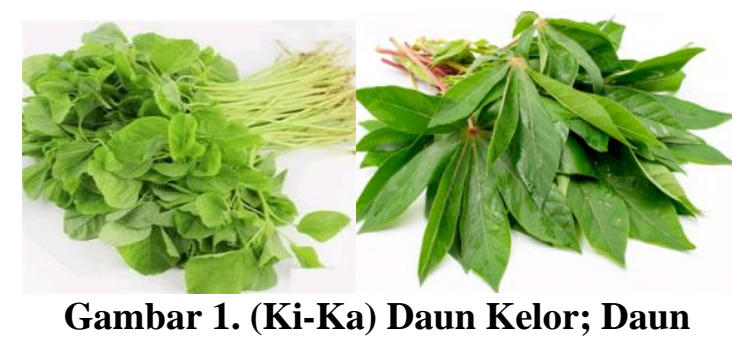
Bayam dan Daun Ubi

Sistem pertanian vertikultur adalah sistem budidaya pertanian yang dilakukan secara vertikal atau bertingkat. Sistem budidaya pertanian menggunakan teknologi vertikultur secara vertikal atau bertingkat ini merupakan sistim penghijauan yang sangat sesuai dan direkomendasikan untuk daerah perkotaan dengan lahan pekarangan yang terbatas atau sempit. Namun tidak menutup kemungkinan, sistem budidaya ini bisa dilakukan di kawasan pedesaan dengan memanfaatkan barang-barang bekas dan sederhana di sekitar tempat tingga. Jika pada lahan seluas 1 meter persegi biasanya hanya bisa untuk menanam 5 batang tanaman, pada sistem vertikal menggunakan teknologi vertikultur bisa menghasilkan lebih dari 30 
batang tanaman tergantung jenis tanaman dan kebutuhan.

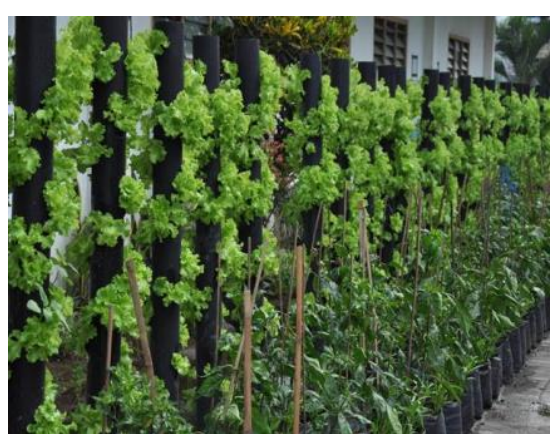

\section{Gambar 2. Aplikasi Budidaya Tanaman} Sayuran dengan Metode Vertikultur

Pemilihan tipe, bahan, ukuran, serta wadah yang akan digunakan untuk budidaya vertikultur sangat bervariasi dan banyak macamnya. Pembudidaya hanya menyesuaikan dengan kondisi dan keinginan, dapat berbentuk persegi panjang, segi tiga, atau dibentuk mirip anak tangga, dengan beberapa tingkatan atau sejumlah rak. Bahan dapat berupa bambu atau pipa paralon, kaleng bekas, bahkan lembaran karung beras yang dipasang pada dinding. Persyaratan aplikasi teknologi vertikultur yang harus dipenuhi dalam budidaya sayuran di lahan pekarangan yang sempit adalah harus memiliki nilai estetika atau keindahan, sehingga selain dapat menghasilkan sayuran sehat dan bergizi untuk dikonsumsi, juga dapat memperindah halaman rumah. Selain itu persyaratan lainnya adalah bahan harus kuat dan mudah untuk di pindahkan.

Agar hasil panen nantinya dapat dikonsumsi untuk berbagai kalangan baik balita maupun orang yang sedang sakit, penggunaan teknologi vertikultur sebaiknya tidak disertai dengan penerapan budidaya bebas pestisida kimia atau sebaiknya menggunakan biopestisida. Budidaya tanaman sayuran secara vertikultur ini juga mudah diterapkan di pekarangan rumah untuk memenuhi kebutuhan pangan dan gizi keluarga sehari-hari sehingga dapat menghemat. Tanaman sayuran pencegah stunting juga diharapkan dapat dibudidayakan menggunakan sistem budidaya vertikultur ini karena cara membuatnya yang mudah dan efisien. Keuntungan budidaya sayuran terutama pada tanaman pencegah stunting dengan sistim vertikultur antara lain : 1). Efisien dalam penggunaan lahan, (2) Mudah dalam pemeliharaan, 3) Penghematan pemakaian pupuk dan biopestisida, (4) Praktis serta mudah dalam upaya mengontrol pertumbuhan rumput dan gulma, (5) Mudah dipindahkan, (6). Tanaman sayuran yang dipanen lebih bersih dan sehat. Terdapat tiga aspek yang harus dipersiapkan dalam budidaya tanaman secara vertikultur dan akan diulas secara jelas pada buku ini, yaitu :

(1) Pembuatan tempat vertikultur

(2) Penyiapan dan penggunaan pupuk organik

(3) Penanaman dan pemeliharaan

\section{METODE PELAKSANAAN PENGABDIAN}

\section{Tempat dan Waktu Pengabdian}

Pengabdian ini telah dilaksanakan pada hari Sabtu, 14 September 2019 di Desa Buntulia Kecamatan Duhiadaa Kabupaten Pohuwato Provinsi Gorontalo.

\section{Bahan dan Alat Pengabdian}

Bahan yang digunakan dalam kegiatan pengabdian Vertikultur menggunakan pipa paralon adalah sebagai berikut :

- Gergaji besi

- Meteran

- Pemanas, kamu bisa menggunakan hair dryer atau lampu teplok

- Pipa paralon berukuran besar

- Kayu berbentuk tabung atau bisa juga menggunakan botol minuman ringan

- Tanah

- Pupuk kompos atau pupuk kandang

\section{Cara membuat :}

1. Setelah semua alat dan bahan sudah siap, buat wadah media tanam yang terbuat dari pipa paralon.

2. Buat gambar pada pipa paralon yang nantinya akan dibuat menjadi luabang.

3. Gergaji gambar yang sudah dibuat tadi.

4. Setelah digergaji, panaskan salah satu sisinya lalu kemudian tekan ke bagian dalam menggunakan botol saat pipa paralon masih lunak.

5. Buat dudukan dari semen agar media bisa dipindah-pindahkan.

6. Tanam pipa paralon di atas tanah secara langsung. 
7. Masukkan media tanam yang terdiri dari campuran tanah dan pupuk.

8. Media tanam vertikultur siap digunakan untuk menanam.

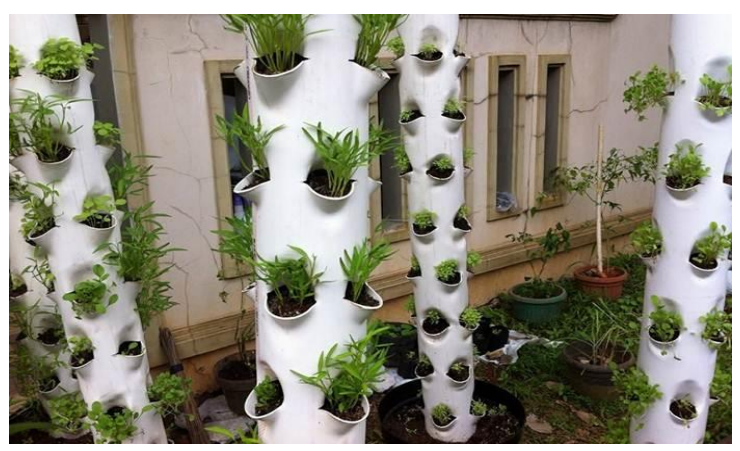

Gambar 3. Contoh Vertikultur menggunakan pipa paralon

Sedangkan bahan dan alat yang digunakan dalam kegiatan pengabdian Vertikultur menggunakan botol bekas adalah sebagai berikut :

- Botol plastik bekas yang berukuran 1,5 liter

- Tali tambang

- Gunting atau cutter

Cara membuat media vertikultur dari bahan botol bekas adalah sebagai berikut :

1. Siapkan botol yang akan kita gunakan sebagai pot untuk tanaman.

2. Buat lubang berbentuk persegi panjang dengan lebah sekitar $3 \mathrm{~cm}$.

3. Buat lubang kecil di bagian bawah dengan diameter sekiar $0,5 \mathrm{~cm}$.

4. Setelah itu buat lubang untuk menempatkan tali gantungan. Lubang berukuran sekitar 1 $\mathrm{cm}$, lalu masukkan tali dan buat simpul pada ujung tali.

5. Masukkan media tanam ke dalam botol plastik yang sudah disulap menjadi pot.

6. Gantung pot pada tembok yang sudah kamu pilih untuk menanam berbagai tanaman

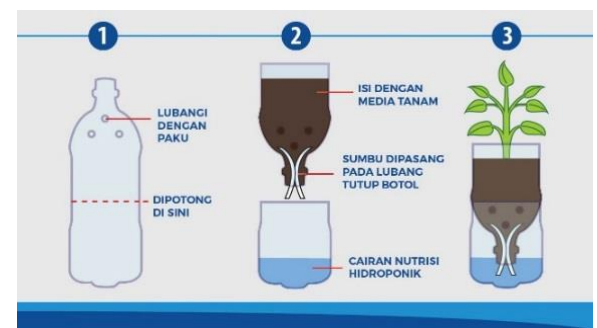

Gambar 4. Contoh vertikultur menggunakan botol bekas

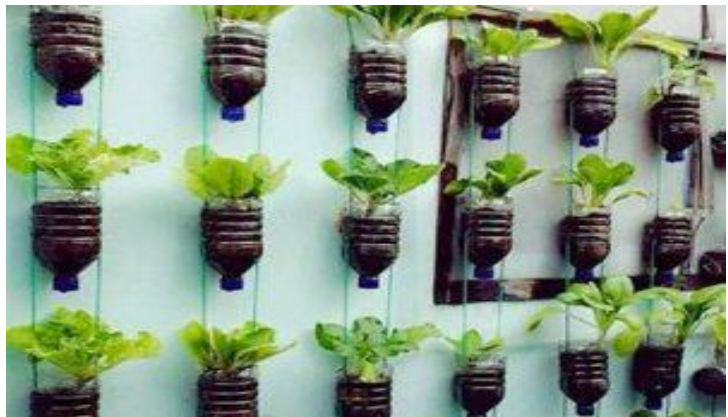

Gambar 5. Hasil vertikultur menggunakan botol bekas

\section{HASIL DAN PEMBAHASAN}

Hasil dari kegiatan pengabdian ini berupa instalasi hidroponik vertikultur

\section{KESIMPULAN DAN SARAN}

Kegiatan menanam tanaman tinggi zat besi dan asam folat di pekarangan rumah (daun kelor, daun bayam hijau dan daun ubi) untuk memenuhi kebutuhan ibu hamil dan MPASI balita dapat dilakukan dengan menggunakan metode budidaya hidroponik atau vertikultur sehingga selain dapat meningkatkan nilai tambah tanaman dan biaya yang dikeluarkan untuk membeli sayuran menjadi lebih efisien

\section{UCAPAN TERIMA KASIH}

Terima kasih kepada Politeknik Gorontalo atas bantuan hibah pengabdian masyarakat tahun 2019.

\section{DAFTAR PUSTAKA}

Dinas Kesehatan. 2015. Profil Dinas Kesehatan Gorontalo 2015

Moeloek. 2019. Cegah Stunting untuk Tingkatkan Kualiatas Sumber Daya Manusia. www.depkes.go.id. Diakses tanggal 19 Agustus 2019

Riskesdas. 2018. Riset Kesehatan Dasar 2013 